\title{
EGY ELLÁTÁSI LÁNC SZIMULÁCIÓJÁNAK TAPASZTALATAI
}

A szimulációt és játékokat széles körben alkalmazzák rendszerelemzésre és az oktatásban. Összetett jellegüknél fogva az ellátási láncok megfelelō tárgyaik az ilyen jellegú vizsgálatoknak. Az elmúlt években a kutatók sokrétú tapasztalatot szereztek a jól ismert sörjátékkal. Jelen cikk kétféle alkalmazást mutat be: 1. újszerú tanulságokat a hagyományos játékból, 2. a sztochasztikus igényt tartalmazó továbbfejlesztett változattal kapcsolatos tapasztalatot. A játéknak sokféle tanulsága van: rendszerdinamika, rész és globális optimumok, illetve célkitúzések, irányítási vonatkozások, az információ és döntés viszonya, az elórejelzés fontossága, szervezeti tanulás és viselkedés.

Kulcsszavak: sörjáték, üzleti szimuláció, rendszerdinamika, készletezési stratégia, készletezési politika

A játékot az MIT Sloan School of Managementben fejlesztették ki annak érdekében, hogy rendszerkoncepciót és rendszerekben való gondolkodást tanítsanak menedzsereknek (Goodwin et al., 1994). Jay Forrester szektordinamikai kutatásai részeként az 1960-as évek elején a Rendszerdinamikai Csoport hozta létre (Sterman, 1992). A játék ellátási láncok versenyét valósítja meg.

Az egyszerú játék sok olyan - közöttük rendszerszemléleti, rendszerdinamikai, irányításelméleti, lélektani, csoportdinamikai - problémát vet fel, illetve szemléltet, amelyek a szervezetek napi gyakorlatában is jelen vannak. Mivel a résztvevók ezeket személyesen megtapasztalják, nemcsak megjegyzik (ismeretté válik), hanem befolyásolja a további viselkedésüket (fejleszti a kompetenciákat). Még az olyan, az oktatásban gyakran hangoztatott, ma már közhellyé vált elv is például, hogy ,a részrendszer optimuma helyett az összrendszer optimumára kell törekedni" is valós tartalommal telik meg. Kiderül, hogy könnyú ezt elfogadni a rendszeren kívülról (felülről), de belsố résztvevő́ként nemcsak az ilyen döntési helyzetet nehéz felismerni, de maga a döntés meghozatala is problémás, hiszen látszólag az összrendszer céljaival ellentétesen, altruista módon kell dönteni, ami a való életben ráadásul ellentétes az ösztönzőrendszer által közvetített elvárásokkal. A játék egyfajta bizonytalan információellátás melletti optimalizálásnak is tekinthetô, amely problémakörre szemléletes példákat hoz- nak Koltai és szerzôtársai (2009). A magasabb rendú optimumok témakörével foglalkozott Vörös (1981, 1999) is. A játéknak jelentôs irodalma van. Ezek egy része a kifejlesztô kutatói múhelyból származik. (Sterman, 1992)

Peter Senge egy fejezetet szentel a magyarul is megjelent The Fifth Discipline (Az ötödik alapelv) címú munkájában a sörjátéknak, mint egy példa a gondolkodásunkban meglévő korlátokra (Senge, 1990).

A játéknak léteznek számítógépes változatai (Coakley et al., 1998). On-line módon az interneten is játszható (http://beergame.mit.edu, http://www. masystem.com/o.o.i.s/1365, http://www.beergame.lim. ethz.ch/) .Többféle fejlesztési környezetben szimulációs modellek is készülttek a játékra (Kumar et al., 2007). Az idốk során különböző változatok készülttek el, amelyek múködését elemezték (D’Atri et al., 2009). Jelen cikk szerzőjje Hollandiában olyan játék lebonyolításában vett részt, amelyben nem négy-, hanem ötszereplős volt az ellátási lánc. A játék saját továbbfejlesztését a „Saját alkalmazási tapasztalatok" címú fejezetben mutatjuk be.

\section{Szabályok}

A játékot egy táblán játsszuk, amely a sör gyártását és elosztását mutatja (1. ábra).

Mindegyik csapaton belül különböző helyek vannak, amelyeket az ellátási lánc szokásos szereplói szerint nevezünk el: kiskereskedő, nagykereskedő, elosztó 
A sör-játékban szimulált ellátási lánc. (Sterman, 1992 alapján)

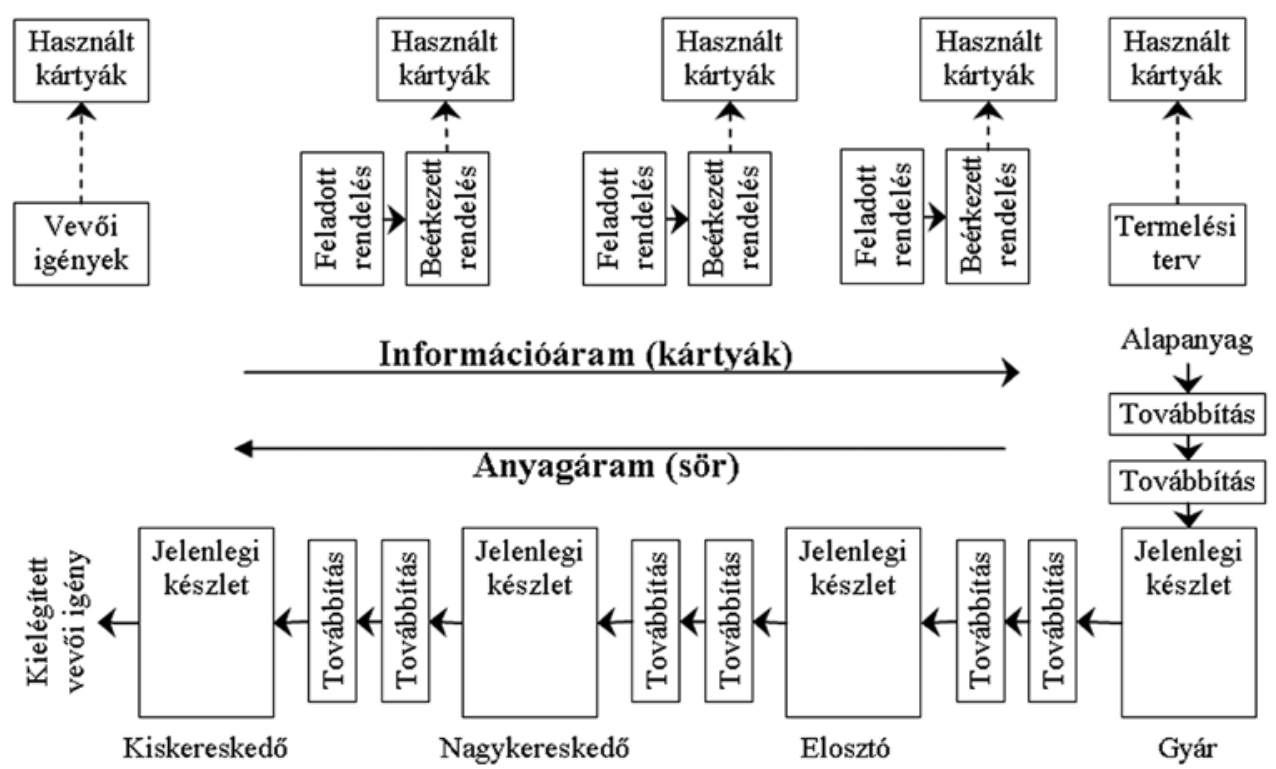

1. ábra a rendelés feladásának, a készletek nyilvántartásának módját. Ezen idó alatt a vevôi igény nem változik, 4 rekesz/hét értéken marad, ebból adódóan mindegyik játékosnak 4-et kell rendelnie az egyensúly megtartásához.

A negyedik héttől kezdődően a játékosok annyit rendelhetnek, amennyit csak akarnak, és ennek következtében tőlük is változó mennyiséget fognak igényelni. Az egyik feladatuk éppen az igények elôrejelzése lesz. A játék 50 szimulált hét után ér véget.

Mindegyik résztvevő- és gyár (K,N,E,GY). Ezek egy lineáris elosztási lánc szerint kapcsolódnak egymáshoz, a múködésük hasonló: mindegyik rendelkezik készlettel és lehetôsége van rendelésre. Egy vagy két ember irányít minden szektort. A vevoói igényeket kártyákra írják rá, feladják és szimulációs lépésenként (szimulált hetenként) továbbítják. A végfelhasználói igényeket egy előre megírt kártyaköteg (az ábrán ,vevői igények”) tartalmazza. Egy rekesz sört egy pénzérme képvisel.

Minden szimulált héten a felhasználók (vevớk) vesznek sört a kiskereskedőtól, aki az igényelt mennyiséget kiszállítja a készletből. A kiskereskedő rendelést ad fel a nagykereskedőnek, aki a készletból kiszállítja az igényelt mennyiséget.

Hasonló módon a nagykereskedô is rendel és kap sört az elosztótól, aki a gyártól rendeli a sört, ahol fôzik. A termelés, a szállítás, valamint a rendelésfeldolgozás idôigénye miatt mindegyik fázisban bizonyos idốt el kell tölteni a sörnek és a rendelési kártyáknak is. A játékosok célja a csoport összköltségének minimalizálása.

A készlettartási költség 0,50 €/rekesz/hét. A hiányköltség $1 € /$ rekesz, ami tartalmazza az elmaradt árbevételt és a vevoók jóindulatának elvesztéséből származó költséget. Hiány esetén az igény fennmarad. A költségeket az elosztási lánc mindegyik pontjánál gyújtik.

A játék bárhol játszható, négy és száz fő közötti résztvevővel.

A játék kiegyenlített állapotból indul. Mindegyik készlet 12 rekesz sört tartalmaz, a kezdeti átbocsátás 4 rekesz/hét. Az elsố négy héten a játékosok megtanulják nek pontos információi vannak a saját részlegéról, a többiról azonban csak korlátozottak az ismeretei. Heti nyilvántartást vezetnek a készletükról, a hiányról és a szállítónak küldött rendelésról.

A rendeléseken és szállításokon kívül minden más kommunikáció tilos a csapatok között. A vevői igényeket egyik játékos sem tud(hat)ja elóre. A játék elôrehaladásával csak a kiskereskedô (és csak a saját vevóinek az igényét) tudja meg. A többieknek csak az jut tudomására, hogy tốlük a saját vevốik mennyit rendelnek.

Ezek az információbeli korlátozások azt jelentik, hogy a játékosok nem tudják döntéseiket összehangolni, vagy közös stratégiát kidolgozni, hiába a költségek minimalizálása mindegyik csapat célja. A valós élethez hasonlóan a globális optimalizálási problémát itt is szét kell bontani a szervezet különbözó helyein megjelenó al(rész)problémákra.

A játék nagyon egyszerú a valós élethez képest. Csak annyit kell tenni, hogy a beérkezó igényeknek megfelelóen a szállítótól elégséges mennyiséget rendeljenek, tartsák alacsonyan a készletszintet és kerüljék el a hiányt. Nincsenek gépleállások vagy más véletlen események, munkaeró-problémák, kapacitáshiány vagy pénzügyi korlátozások.

Felhívjuk a figyelmet arra, hogy senki ne maradjon le, ne haladjon gyorsabban a játékvezetố által megadott ütemhez képest. A tábla kialakítása lehetôvé teszi a játékvezetố számára a vizuális alapon történó irányítást, így a nem megfelelőség - némi gyakorlat után - könynyen észrevehetô. 


\section{Saját alkalmazási tapasztalatok}

A Pannon Egyetemen (a korábbi Veszprémi Egyetemen) 1997 óta használjuk a sörjátékot különböző képzéseken belül (MBA, menedzser és minőségügyi szakmérnöki, mérnök-közgazdász szakirányú továbbképzések [kiegészítő] közgazdászképzések, valamint különböző továbbképző tanfolyamok). A szerző vezetett még játékot Ausztriában és az NSZK-ban. A játékok általában jó hangulatban zajlanak, összekovácsoló jellegük is van.

\section{Determinisztikus igények szimulációja}

Ez gyakorlatilag a klasszikus játék megismétlését jelenti. Az a célja, hogy tapasztalati hátteret jelentsen a különbözô szervezeti folyamatok, jelenségek alapos megbeszéléséhez. A továbbiakban nem annyira a játékot, mint a saját kiértékelési tapasztalatainkat mutatjuk be.

Az is cél, hogy a szimuláció döntéshozatali mechanizmusát a résztvevók a második részhez - sztochasztikus eset - megismerjék. A játék végén diagramokat rajzolunk az idő függvényében:

- készlet vagy hiány,

- saját rendelés,

- vélemény arról, hogy vajon milyen volt idôszakról idôszakra a felhasználói igény.

Általában a 2-4. ábrákon láthatóhoz hasonló diagramokat kapunk. Ezek az eredmények megegyeznek a szakirodalomban találhatókkal (Sterman, 1992). Az egyes diagramok sorrendje balról jobbra: kiskereskedő, nagykereskedó, elosztó, gyár. Az ábrákkal lehet szemléltetni az ellátási láncokban fellépő ostorcsapás (bull whip) effektust.

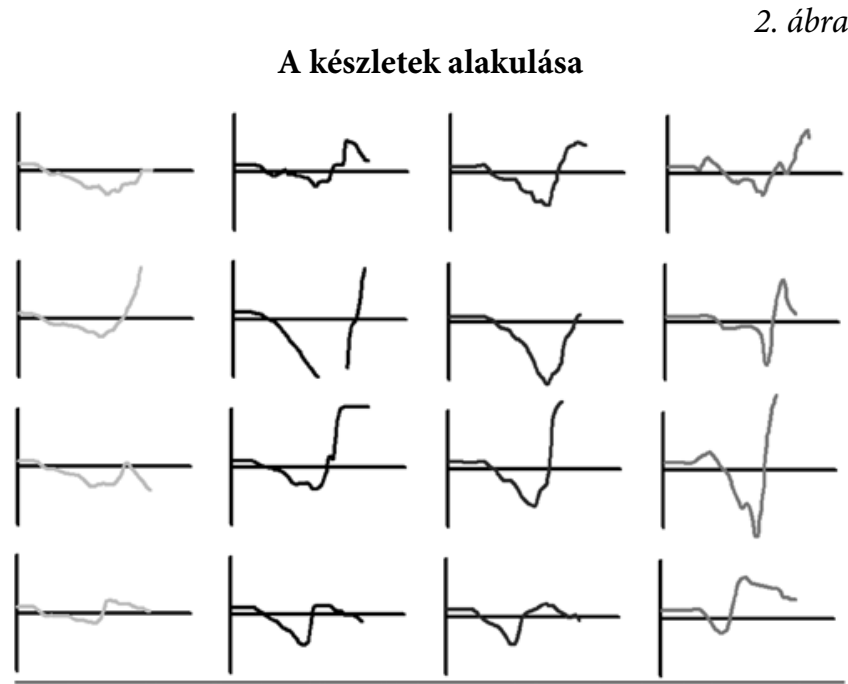

A készletábrákon az időtengely feletti rész a készletet, az alatti a hiányt mutatja. Látható, hogy az ostorcsapás effektus megjelenik. Gyakran a kitérések amplitudója és hullámhossza a kiskereskedôtól távo- lodva egyaránt nô. Kellemetlen a résztvevóknek szembesülniük azzal a ténnyel, hogy egy csapaton belül egyidejúleg fordul elő készlet és hiány (3. ábra).

\section{A saját rendelések alakulása}

3. ábra

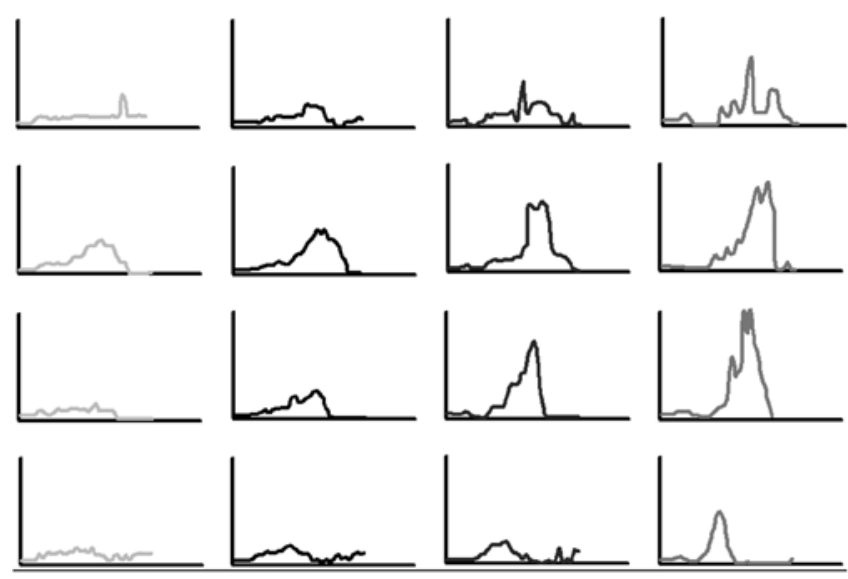

Az ostorcsapás effektus, illetve annak következménye megjelenik a saját rendelések esetében is. A kiskereskedôtól térben, a kiindulási állapottól kezdve pedig idôben nőnek a rendelések. A döntéseket a 2. ábra alapján hozták meg, az itteni lengések az ottaniak egyenes következményei (4. ábra).

4. ábra

Vélemény

a tényleges végfelhasználói igényről
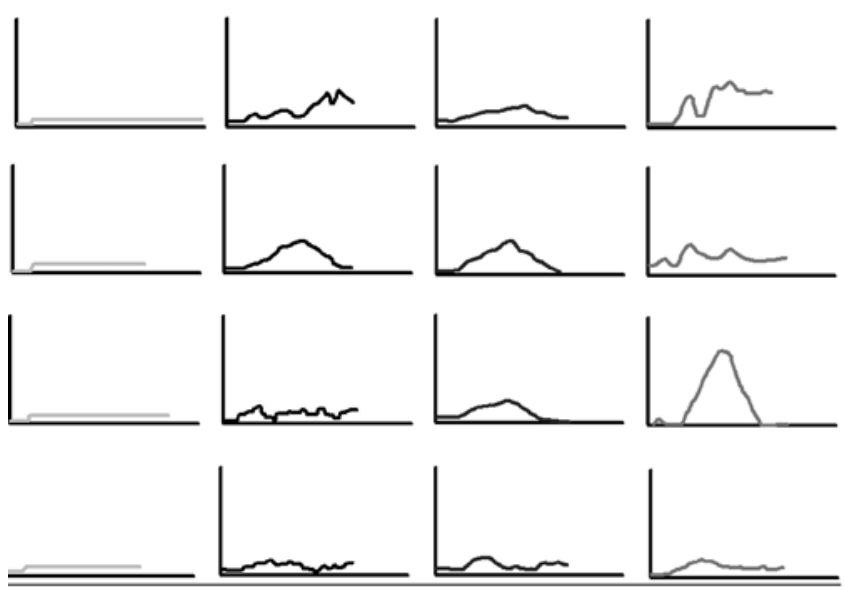

Nagyon tanulságos megfigyelni, hogy a végfelhasználótól való távolság függvényében egyre hamisabb képet alkotnak maguknak a résztvevók a végfelhasználó tényleges igényéról. (Mint már említettük, a kiskereskedő volt az egyetlen, aki ismeri a tényleges igényeket.)

Az ábrák megrajzolása és kifüggesztése után a résztvevốk általában meglepődnek. Ekkor közöljük, hogy a játék valódi célja az volt, hogy alapot szolgáltasson a következő kérdések megbeszéléséhez: 
Ki vitte a lengést a rendszerbe?

Érezhetôvé válik az egyéni és szervezeti tanulási folyamat, ahogyan a résztvevók mások - általában a gyár vagy kiskereskedő - megnevezésétól eljutnak önmagukhoz, illetve a teljes csapathoz. Érdekes a gyár helyzete: kapacitásának és az alapanyag mennyiségének nincs korlátja. Ennek ismeretében általában higgadtan hozzák meg döntéseiket. A hiányok megjelenésekor már fogalmazódnak meg kritikák a gyárral szemben a többi csapattag részéról (a tiltott kommunikáció ellenére). A gyárak valójában ekkor követik el a hibát: válaszul a hiányra az indokoltnál nagyobb mértékben futtatják fel a termelést. Amint az a 4. ábráról látszik, döntéseiket a hiány által eltorzított, hamis információ alapján hozzák meg. A csoportdiszkusszió során ez két fontos terület megbeszélését teszi lehetővé:

- az információ és a döntés viszonya: nem lehet egy szervezetben nagy döntési szabadságot adni oda, ahol rossz az információkkal való ellátottság,

- az előrejelzés fontossága: tervezni csak megfeleló előrejelzési információk birtokában szabad.

Egy alkalommal elvégeztünk egy olyan kísérletet, ahol a gyár ismerte a játék szabályait, és - vállalva a csoporttársak kemény kritikáját - ellenállva a nyomásnak és a korlátlan kapacitás adta lehetőségnek, nem futtatta fel a termelést az átmeneti hiány által látszólag megkívánt mértékben. Ezáltal csökkentette a kilengést, és a csapat megnyerte a játékot.

\section{Miért lett hiány?}

A játék kiindulási állapota csalóka képet mutat, még a kiskereskedô számára is. (Egyébként a hatás érdekében ôt kell először becsapni.) Az átlagos igény 8, a kiindulási készlet pedig 12, bóven elegendőnek túnik. Sôt, ehhez adott időszakban még 4 be is érkezik, tehát a kiszállítás eloótt rendelkezésre álló mennyiség a duplája az igénynek. A következô két idôszakban azonban csak 4-4 fog beérkezni. Az elsố három időszakban tehát az összes rendelkezésre álló mennyiség 24, és az igény is 24. Ekkorra azonban a készlet(ek) nullára csökken(nek). Ha a rendszer többi tagja a próbajáték alatti 4 igényról nem áll át 8-ra - és általában nem teszik, a gyár és az elosztó biztosan nem -, akkor a rendszerben hiány lép fel. Ez pánikreakciót eredményez, ami beindítja a lengéseket.

\section{Miért nem lehetett jól játszani?}

Az általánosan megfogalmazódó válasz, hogy a tiltott kommunikáció miatt kevés volt az információ. Az indoklás természetesen nem teljesen igaz, hiszen a rendelések révén valójában volt kommunikáció. A helyzet rávilágít arra, hogy egy szervezetben a - döntésekhez feltétlenül szükséges (need to know) információk mel- lett fontosak az egyéb, az összefüggéseket mutató (nice to know) információk is. A kialakuló következtetések:

- fontos az elốrejelzés,

- nem volt információ(tudás)megosztás,

- az információellátottság és döntési szabadsági fok kapcsolata:

- a gyárnak nagy a szabadsági foka (korlátlan anyagellátás és kapacitás, önmagától rendel [termelést tervez]), de kevés az információja,

- a kiskereskedőnek jobb az információellátottsága, de korlátozottak a lehetôségei.

- szükséges olyan információrendszer, ami támogatja a döntéseket.

Mi volt a rendszer célja?

A válasz egyértelmú: a csapat - ellátási lánc - minimális összes költsége.

Mire törekedtek a saját helyükön?

Tipikus válaszok:

„Kevés költséget okozzak.” „Elégítsem ki a vevőt.” „Költségminimalizálás.”

Nagyon meglepődnek, amikor a játékvezetô részéról erre az a válasz érkezik, hogy éppen ez volt a hiba. Megállapítjuk, hogy a maga helyén mindenki optimális döntést hozott, és tekintettel a játék egyszerúségére, ezt jól meg is tudta valósítani. A következő kérdés elvi jellegú:

A részrendszerek optimuma garantálja-e az összrendszer optimumát?

Természetesen a válasz „nem”. Utalunk arra, hogy ezt bizonyára már többször is hallották, ismerik. A játék kapcsán azonban igazi értelmet nyert, nem a saját részrendszer optimumára kellett volna törekedni.

Hogyan kellett volna eltérni a részrendszer optimumától, hogy a teljes rendszer múködése legyen optimális?

Ez általában nem bizonyul könnyú kérdésnek. A költségminimumra törekvés helyi szinten nagyon logikusnak túnik. Ha ettól eltérünk, az látszólag szembemenetelt jelent az összrendszer céljaival. A konkrét játékban a megoldás: nem kellett volna olyan gyorsan a saját hiányt megszüntetni. Ehelyett idônként átmenetileg kellett volna vállalni a hiányt, nem rárendelni, ha a másik nem tud szállítani. Ugyanígy, ha nem rendel, akkor csak nála lesz hiány, azonban ha úgy rendel, hogy a másik nem tud szállítani, akkor a csapatánál két helyen lesz hiány: nála és a beszállítójánál is. A pillanatnyi helyzet helyett inkább az, hogy az addigi összes rendelés és összes beérkezés különbségét kellett volna nézni. Ennek irányításelméleti vonatkozása is van: nem a pillanatnyi különbségre, hanem a halmozott (integrált) eltérésre kell szabályozni. 
A megbeszélés során megállapítjuk, hogy a gyakorlatban ezt végrehajtói szinten nem is könnyư megtenni. Hiszen aki ezt felvállalja, az szembemegy a szervezeti céllal, szervezeti kudarc esetén könnyen búnbakká válik.

Hogyan lehet ezt elkerülni?

A válasz általában játékvezetői közremúköódéssel születik meg: a részrendszerek céljainak megfelelố meghatározásával. Konkrétan megfogalmazva: a részrendszerek céljait nem szabad mereven származtatni az összrendszer céljá(i)ból. Ez tulajdonképpen ,a részrendszerek optimuma nem garantálja az összrendszerek optimumát" állítás megfordítása, de a gyakorlatban hasznosabb, hiszen a célok kitúzésére vonatkozó állítás arra is választ ad, hogy mit (nem) kell/ szabad tenni a rendszerszintú optimum elérése érdekében. Ha a megfelelố célok kitúzése megvalósul, a döntés felelőssége nem a végrehajtókra hárul. Csak kevés olyan szervezet van, ahol a végrehajtásban résztvevók felkészültsége és felhatalmazása lehetôvé teszi ilyen döntések meghozatalát. Inkább követik a szervezeti célból mechanikusan származtatott, de annak csak látszólag megfeleló helyi célokat.

Konkrétabb példaként a szervezetekben idônként felbukkanó fünyíró elvet említjük: például megszorítási kényszer esetén mindenkire azonos mértékú megszorítás kivetése. Fontos tehát, hogy a menedzsmentoktatásban a fenti problémakörnek ne csak az optimalizálási, hanem a célkitúzési vonatkozásokat is megemlítsük.

\section{Mindehhez ki/mi hiányzott a rendszerból?}

Némi rávezetés után megállapítjuk, hogy a vezetô, a vezetés, annak minden funkciójával.

\section{Milyen hosszú volt a lánc?}

A gyorsan érkezô válasz, amely a munkahelyek számából indul ki: 4. Kérjük, hogy a lánc hosszát idóben fejezzék ki, ekkor már nagyobb értékek, 8, 10 hangzanak el. Segítségképpen a kérdést átfogalmazzuk: Ha a próbajáték után az igény 100 lenne, mennyi idó múlva kapná meg a vevő? Ekkor már nemcsak a termék-, hanem a rendeléstovábbítási idóket is figyelembe veszik. Alaposabb átgondolás után 20-hoz közelítő értékek hangzanak el. Megállapítjuk, hogy egy ellátási lánc hosszát nemcsak az anyag-, hanem az információáramlás időigénye is befolyásolja. Gyakorlati példaként a Magyarországon elóforduló leghosszabb szállítási útvonal bejárásának és a rendelésekkel kapcsolatos tevékenység elvégzésének idôigényét vesszük.

Beállt volna-e a rendszer állandó állapotra, ha a játékot sokáig játsszuk?

A legtöbb esetben határozott „,igen” a válasz. Ezt így is gondolják, mert a játék abbahagyását is általában tiltakozás kíséri: „éppen most jöttem volna rendbe a készletekkel”, „folytassuk még”. Egy diplomadolgozat keretében elvégzett számítógépes szimuláció azt mutatta, hogy a rendszer bármikor képes lengésbe jönni egy átmeneti stabilizálódás után. Ugyanakkor elképzelhetô, hogy emberi szereplő́k esetén - az egyébként tiltott - verbális és non-verbális kommunikációból adódó információszivárgás végül a vevôi igénynek megfelelő stacioner állapothoz vezet.

A következô fordulót is előkészítendô néhány további, kevésbé stratégiai, inkább technikai, rendszerdinamikai kérdést is megbeszélünk.

Mit változtatnának a szabályokon, hogy a játékot a korábbinál sikeresebben lehessen játszani?

Ez tulajdonképpen egy optimális múködésú rendszer megvalósítását jelenti. A leggyakoribb ötletek: az információ megosztása, vezető/koordinátor kijelölése, a lánc hosszának csökkentése.

Milyen szabályozási formákat alkalmaznának (vezérlés, visszacsatolás, elórecsatolás)?

A visszacsatolás megvalósult, de csak helyi szinten. Elốrejelzést igénylő előrecsatolást legfeljebb a kiskereskedő tudott alkalmazni. A lengések egyfajta gerjedésre is utalnak.

\section{Hol lépett be az igény a rendszerbe?}

A játék táblájának kialakítása vizuálisan is mutatja, hogy egy tisztán húzórendszerról van szó. Úgy túnik azonban, hogy itt a húzó rendszer elónyei helyett annak csak a hátrányaival szembesültünk: nincs rálátás a folyamatra, a résztvevốk csak a szomszédaikat „látják”, helyi irányítás alkalmazása. Utalunk arra, hogy ez szomorú, hiszen a gyakorlatban a húzórendszerek nagyon sikeresek tudnak lenni. Példaként megemlítjük a kanbant és a Toyota termelési rendszert. Provokatívan megkérdezzük, hogy talán tolórendszer jobb lett volna-e.

Az egyes csapatok egy újrajátszás esetén milyen egy idôszakra jutó költséggel tudnák játszani a játékot állandósult múködési állapotban?

A játékot az előzetesen bejelentettnél korábban fejezzük be, hogy az ,end effectet”-et elkerüljük. Ezt általában elégedetlenség kíséri, mivel úgy gondolják, hogy már csak néhány időszak kellene, és ,beállnának” állandósult állapotba. A kérdés arra vonatkozik, hogy ebben az általuk elérni kívánt és remélt állapotban milyen időszakonkénti költséggel lehetne játszani a játékot.

Itt konkrét számszerú vállalásokat várunk. Általában a költségek megfelezését, több körben annál kevesebbet is vállalnak. Elóbb-utóbb mindig akad valaki, aki rájön arra, hogy a játék valójában nulla költséggel is játszható, ha nincsenek raktári készletek, csak úton

\section{VEZETÉSTUDOMÁNY}


lévốk. Ennek nevet is adunk: Just in Time. Korábbi tanulmányaik során a JIT 31 előfeltételét/jellemzőjét ismerték meg (Kovács, 2008). Szembesítjük óket azzal, hogy ezekból már az elsốt, az állandó termelési volument sem ismerték fel.

Miért nem játszották a JIT-stratégiát, ha a konkrét játék ideálisan illeszkedik ehhez?

Nyilvánvaló, és ezt a válaszok is megerósítik, hogy ehhez kevés volt az információ.

A játék részben rámutat azokra a JIT/TPS/lean bevezetési és alkalmazási problémákra, amelyeket Kelemen (2009) nagyon részletesen tárgyal, beleértve a rész (nála lokális) optimumok problémakörét.

\section{Sztochasztikus szimuláció}

A szimulációt a saját fejlesztésú metodikával folytattuk, amely jóval életszerúbb módon zajlott. Ennek során az igény egyenletes eloszlás szerint változott 0 és 20 között.

A csoportok (egyes ellátási láncokat megvalósító „vállalatok”) saját múködési módot alakíthattak ki korábbi munkatapasztalataik és az előző - determinisztikus - játék tapasztalatai alapján. Külön felhívjuk a figyelmet arra, hogy hasznosítsák az előző forduló utáni megbeszélés során tanultakat. Ami változatlan volt: nem lehetett munkahelyet elhagyni, a korábbi rendelési és anyagáramlási mechanizmust be kellett tartani.

A második kör tanulságai:

a) A résztvevő́k hajlamosak a stratégiaalkotási folyamat kihívását alábecsülni. A 20 percnyi idôkeretet bőven elegendőnek tartják és - az elôzetes figyelmeztetés ellenére - nem megfelelően használják fel.

b) Ha a második, saját stratégiát megvalósító fordulót az eredeti játék kiinduló állapotából kezdtük, gyakran okozott problémát, hogy nem gondoltak arra, hogy a kiinduló állapotból hogyan jutnak el a tervezett stratégiát megvalósító múködésbe. Az idő szorításában kialakult improvizációs kényszer esetenként konfliktust okozott a csapattagok között.

c) A kidolgozott stratégiák eléggé vegyes képet mutattak. Amint arra felszólítást is kaptak, mindenképpen megpróbálták az első kör tanulságait (törekvés JIT-rendszerre, a kommunikáció és a csapatmunka megszervezése) beépíteni a múködésbe. A többség ugyancsak törekedett valamilyen visszacsatolási szabályozás beépítésére. Igyekeztek eldönteni, hogy a rendszerben hol legyen, és hol ne legyen készlet. Esetenkén rá-

\section{Eredmények sztochasztikus igények esetén}

\begin{tabular}{|c|c|c|c|c|c|c|c|}
\hline Vállalat & 1 & & & Vállalat & 2 & & \\
\hline & $\mathrm{K}$ & $\mathrm{H}$ & Költség & & $\mathrm{K}$ & $\mathrm{H}$ & Költség \\
\hline Gyár & 33 & 103 & 119,5 & Gyár & 325 & 0 & 162,5 \\
\hline Elosztó & 28 & 74 & 88 & Elosztó & 290 & 0 & 145 \\
\hline Nagyker. & 0 & 397 & 397 & Nagyker. & 251 & 0 & 125,5 \\
\hline Kisker. & 3 & 413 & 414,5 & Kisker. & 137 & 138 & 206,5 \\
\hline Össz.: & 64 & 987 & 1019 & Össz.: & 1003 & 138 & 639,5 \\
\hline Költség: & 32 & 987 & 1019 & Költség: & 501,5 & 138 & 639,5 \\
\hline Költség/idó & 2,133333 & 65,8 & 67,93333 & Költség/idő & 33,43333 & 9,2 & 42,63333 \\
\hline \multirow[t]{2}{*}{ Vállalat } & 3 & & & & $\mathrm{~T}, \mathrm{q}$ stratégia & & \\
\hline & $\mathrm{K}$ & $\mathrm{H}$ & Költség & & & & \\
\hline Gyár & 162 & 2 & 83 & & & & \\
\hline Elosztó & 214 & 10 & 117 & & & & \\
\hline Nagyker. & 187 & 10 & 103,5 & & & & \\
\hline Kisker. & 61 & 197 & 227,5 & & Készlet & Hiány & Összesen \\
\hline Össz:: & 624 & 219 & 531 & Mennyiség & 135 & 6 & \\
\hline Költség: & 312 & 219 & 531 & Költség: & 67,5 & 6 & 73,5 \\
\hline Költség/idő & 20,8 & 14,6 & 35,4 & Költség/idő & 4,5 & 0,4 & 4,9 \\
\hline
\end{tabular}


jöttek arra is, hogy a beszállító lehetôségeinek figyelembevételével rendeljenek. (Gyakorlatilag tolórendszer, amit a gyár vezérel a végfelhasználói igényeknek megfelelően.)

A csapatok versengésébe beszállt a játékvezetô is. Az ô stratégiája nagyon egyszerú volt. Állandó termelési ütem, tolórendszerben, a kiskereskedónél 5 nyitókészlettel. (Emögött nem volt tényleges optimalizáló számítás, a készlettartási és hiányköltségek arányán alapuló durva becslésen alapult. A cél a hallgatói stratégiák versenyeztetése egy egyszerú stratégiával, nem pedig az optimális stratégiával volt.) Ez a - visszacsatolást és három helyen készleteket nem tartalmazó - stratégia annyira egyszerú, hogy a játékvezetô képes egyedül irányítani a teljes ellátási láncot, mert csak a kiskereskedónél kell nyilvántartást vezetni. (Ennek is van üzenete a gyakorlat számára.) A készletmodellek elméletében ez az állandó idôközú, állandó tételnagyságú $(\mathrm{T}, \mathrm{q})$ modellek családjába tartozik.

A második kört általában 10 időszakig játsszuk. Teljesítménymutatónak és ezt előre közöltük - az egy időszakra jutó összes költséget tekintjük. Az eredményeket az 5. ábra mutatja. Látható, hogy a játékvezetói eredmény - a T,q megjelölésnél található $4,9 €$ - sokkal jobb, mint a többi vállalat 35,4€ és 67,93 € közötti értékei.

Az ábra csak egy játék eredményét mutatja, de az eddigi játékok során mindig a játékvezető eredménye lett a legjobb (5. ábra).

Itt nem arról van szó, hogy a merev $(\mathrm{T}, \mathrm{q})$ stratégia néha jobb eredményt adott, mint a többi, visszacsatolást tartalmazó stratégia, hanem az eddig játszott játékok esetén minden esetben ez történt.

Meglepő - újszerúnek tekinthetố - eredmény: a viszszacsatolás nélküli (merev), de a készleteket a felhasználó közelébe telepító T,q stratégiával rövid távon jobb eredmény érhetố el, mint a visszacsatolást alkalmazó, de zavaros, több helyen megengedett készletekkel operáló megoldások. Kérdés, hogy ez hosszabb távra is igaz-e? Ennek eldöntéséhez számítógépes szimulációt végeztünk.

\section{Számítógépes modell}

A számítógépes készletezési modellt VisSimben készítettük el. A további vizsgálatokra felkészülve nemcsak egyenletes, hanem normális eloszlás alkalmazhatóságát is beépítettuik. A modell képe a 6 . ábrán látható.

6. ábra

\section{A számítógépi szimulációs modell}

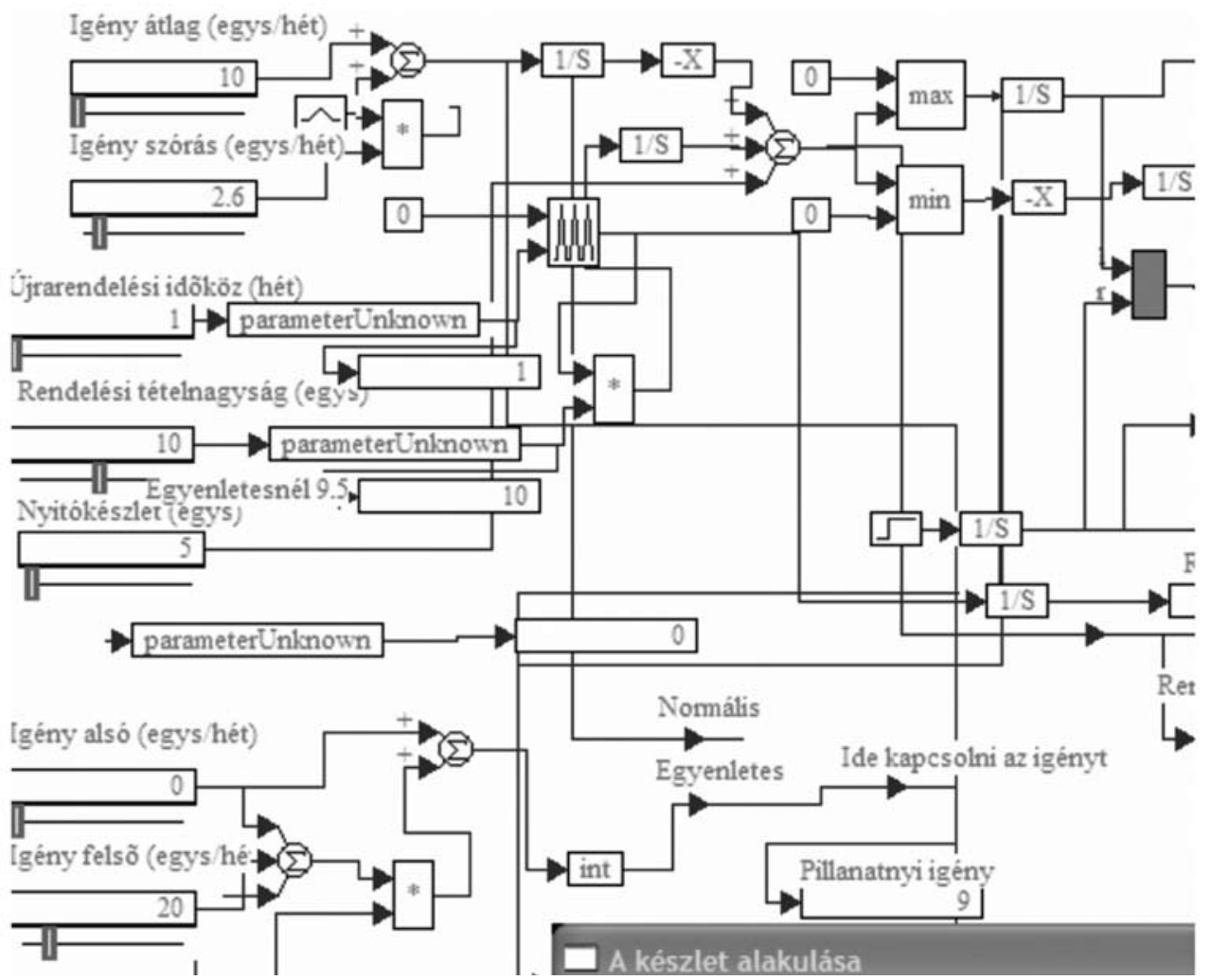

Az első kísérleti összeállításnál az igény 0 és 20 között változott, egész számokkal (7. ábra).

Ahogyan az várható volt, hosszabb távon a $(\mathrm{T}, \mathrm{q})$ mechanizmus rosszul reagált a változó igényekre (8. ábra).

A kézi szimulációnál azért alkalmaztunk egyenletes eloszlást, mert könnyư az ilyen eloszlású számok generálása, a „kártyapakli” elóállítása. A gyakorlatban azonban gyakran fordul elô normális eloszlás, amelynél az adatok kisebb relatív szórása várható. A számítógépes modell lehetôvé tette normális eloszlás alkalmazását is. 1000000 kísérletet végeztünk $n=10 \quad s=2,6$ paraméterû́ normális eloszlású igénnyel, 5 nyitókészlet mellett. A kapott eredmények nem kedvezóbbek az egyenletes eloszlás alkalmazásával kapott eredményeknél (9. ábra). 
Az igények egyenletes eloszlást követtek
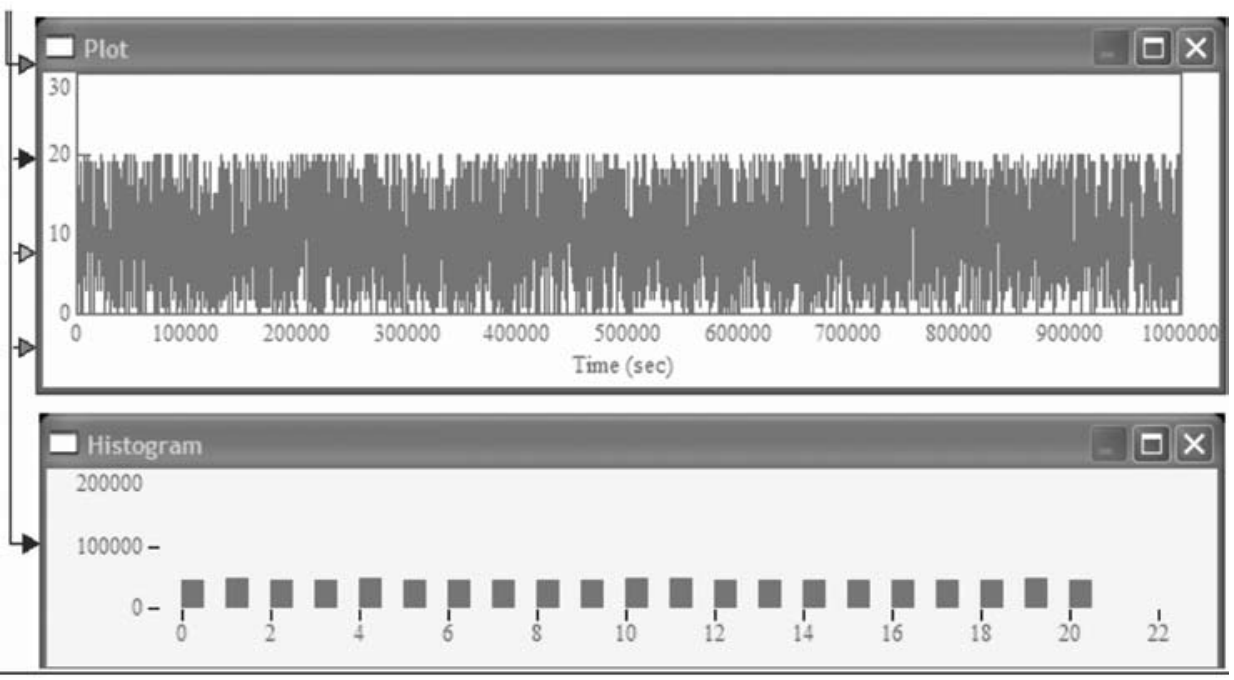

A merev ( $T, q)$ stratégia

hosszú távon rossz választ ad a véletlenszerü igényekre

(egyenletes eloszlású igény)

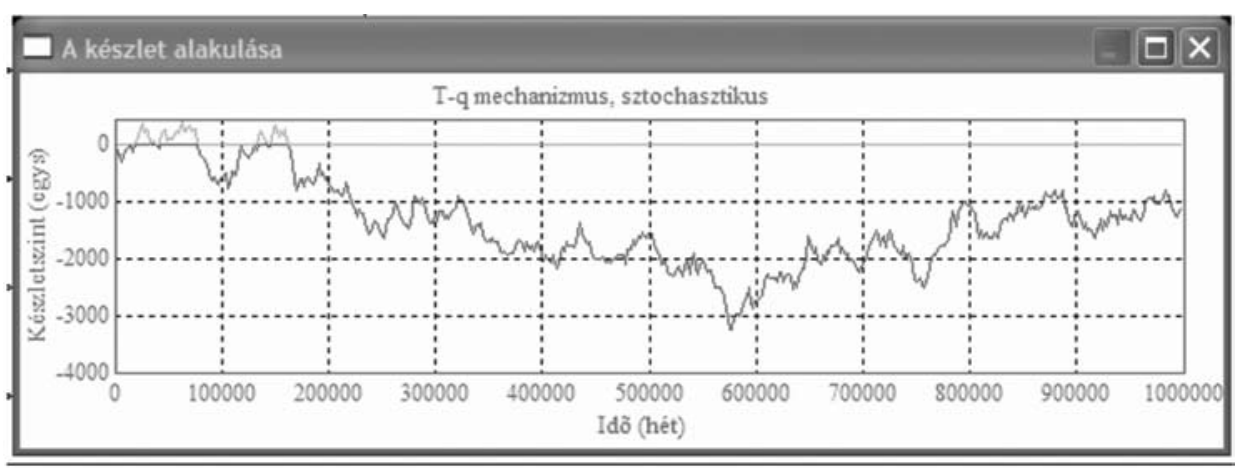

A merev $(T, q)$ stratégia normális eloszlású igény esetén is rossz választ ad a véletlenszerü igényekre hosszú időtávon

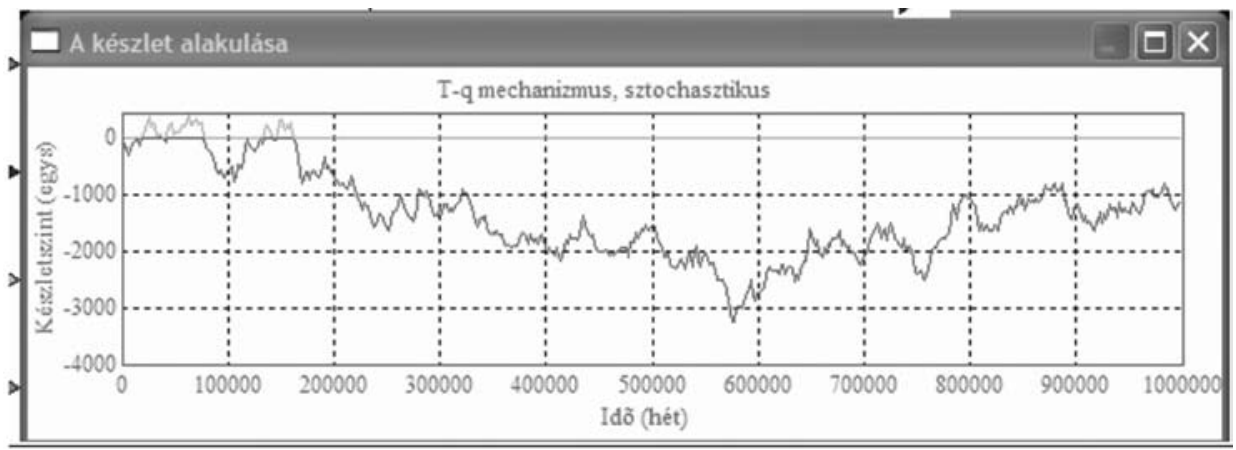

Következtetés, alkalmazás

Az ellátási lánc szimulációt megvalósító sörjáték méltán vált világszerte ismertté és alkalmazottá. A tanulságok sokféle területen alkalmazhatók.

$\mathrm{Az}$ eddigi tapasztalatok azt mutatják, hogy a résztvevớk a különbözó országokban hasonló döntéseket hoznak. A játék oktatási alkalmazása lehetőséget teremt különböző vezetéstudományi vonatkozások alapos megbeszélésére. Az élményszerú kapcsolat révén a megszerzett tudás hosszú távra rögzül.

A továbbfejlesztett játék alkalmas arra, hogy a korábbi fázisban szerzett tanulságok alkalmazási képességét ellenôrizzük. Fejleszti a csoportmunkában történő stratégiaalkotás és megvalósítás képességét.

Rövid távon a visszacsatolás nélküli (merev), de a készleteket a felhasználó közelébe telepítő $(\mathrm{T}, \mathrm{q})$ stratégiával, továbbá a húzó és toló részrendszerek kombinációjával jobb eredmény érhetô el, mint a visszacsatolást alkalmazó, de több helyen készletekkel operáló megoldások. Ez azért lehet fontos, mert a $(\mathrm{T}, \mathrm{q})$ a legkisebb költséggel múködtethetô mechanizmus.

További vizsgálatok szükségesek annak eldöntésére, hogy a merev stratégia milyen idótávig felel meg, illetve milyen szabályozási mechanizmust célszerú alkalmazni.

A játék még feltehetôen sokáig fogja szolgálni a menedzsmentoktatást. ${ }^{1}$ 


\section{Lábjegyzet}

${ }^{1}$ Cikkünk a TÁMOP 4.2.2. projekt keretében történő disszeminációnak is része.

\section{Felhasznált irodalom}

- http://beergame.mit.edu/, 2010. február 6.

- http://www.beergame.lim.ethz.ch/, 2010. február 6.

- http://www.masystem.com/o.o.i.s/1365, 2010. február 6.

Coakley, J.R. - Drexler, J.A. - A.J. - Larson, E.W. - Kircher, A.E. (1998): Using a Computer-Based Version of the Beer Game: Lessons Learned, Journal of Management Education, Vol. 22, No. 3, p. 416-424.

D'Atri, A. - Spagnoletti, P. - Banzato, A. - Bonelli, C. D’Atri, E. - Traversi, V. - Zeno, P. (2009): Supply Chain and Virtual Enterprises: the Beer Game evolution, Proceedings Proceedings of ALPIS. Sprouts: Working Papers on Information Systems, 9(13). http://sprouts.aisnet. org/9-13, 2010. január 22.

Goodwin, J.S. - Franklin, S.G. (1994): The Beer Distribution Game: Using Simulation to Teach Systems Thinking, Journal of Management Development, MCB UP Ltd. Vol. 13 , Issue 8 , p. 7-15.
Kelemen T. (2009): A lean management megvalósításának jellegzetes problémái. Vezetéstudomány XL. évfolyam, 2009. június különszám, p. 62-67.

Koltai T. - Romhányi G. - Tatay V. (2009): Optimalizálás bizonytalan paraméterekkel a termelés- és szolgáltatásmenedzsmentben, Vezetéstudomány XL. évfolyam, 2009. június különszám, p. 68-73.

Kovács Z. (2008): Termelésmenedzsment, Veszprémi Egyetemi Kiadó, Veszprém

Kumar, S. - Chandra, Ch. - Seppanen, M.S. (2007): Demonstrating supply chain parameter optimization through beer game simulation, Information-Knowledge-Systems Management, Volume 6, Issue 4, IOS Press Amsterdam, p. 291-322.

Senge, P.M. (1990): The Fifth Discipline: The Art \& Practice of the Learning Organization, Doubleday Business

Sterman, J.D. (1992): Teaching Takes Off: Flight Simulators for Management Education. OR/MS Today, p. 40-44.

Vörös J. - Csébfalvi Gy. (1981): Magasabbrendú optimumok a termeléstervezésben. SZIGMA 14: p. 2-3.

Vörös J. (1999): Termelési-szolgáltatási rendszerek vezetése, Janus Pannonius Egyetemi Kiadó, Pécs

Cikk beérkezett: 2010. 2. hó

Lektori vélemény alapján véglegesítve: 2010. 3. hó 